\title{
Przegląd metod wykrywania nieszczelności sieci gazowych
}

\begin{abstract}
Wycieki gazu ziemnego z sieci przesyłowej i dystrybucyjnej są poważnym zagrożeniem dla środowiska ze względu na emisję metanu do atmosfery. Niniejszy artykuł stanowi przegląd dostępnych i stosowanych metod wykrywania nieszczelności gazociągów. Opisano w nim metody techniczne, nietechniczne oraz obliczeniowe, szczególnie zwracając uwagę na możliwość wykorzystania tych metod podczas prowadzenia pomiarów wielkości emisji metanu.
\end{abstract}

Słowa kluczowe: gazociągi, sieci gazowe, wykrywanie nieszczelności.

\section{An overview of methods for detecting gas network leaks}

Gas leaks from natural gas transmission and distribution networks are a serious threat to the environment due to the emission of methane into the atmosphere. This article reviews the available and used gas leak detection methods. It also describes the available technical, non-technical and calculation methods including the possible use of these methods when conducting measurements of methane emissions.

Key words: gas pipelines, gas networks, leakage detection.

\section{Wstęp}

Analizy dostępnych w literaturze współczynników emisji metanu wyraźnie dowodzą, że ich duże zróżnicowanie oraz niewielka ilość obiektywnych przesłanek mówiących o tym, który ze współczynników emisji w najlepszy sposób charakteryzuje dany system gazowy, mogą przyczyniać się do uzyskania nieprawidłowych wyników inwentaryzacji emisji metanu w oparciu o te współczynniki $[8,23]$. W celu wyznaczenia własnych współczynników emisji metanu konieczne jest dokonanie pomiarów wielkości emisji metanu z nieszczelności zlokalizowanych na poszczególnych elementach systemu. Pierwszym etapem prowadzenia pomiarów wielkości emisji metanu jest identyfikacja miejsc występowania nieszczelności w obrębie badanych elementów systemu.

W niniejszym artykule scharakteryzowano metody wykrywania nieszczelności, jakie mogą być stosowane dla czynnych gazociągów (bez konieczności wyłączania ich z eksploatacji) i które stanowią pierwszy etap poprzedzający pomiar wielkości emisji metanu. Dobór odpowiedniej metody służącej do lokalizacji nieszczelności zależy od wielu czynników, m.in.:
- wielkości i stopnia skomplikowania obiektu, na którym prowadzone są pomiary,

- lokalizacji nieszczelności (nadziemna lub podziemna),

- minimalnej wielkości nieszczelności, jaka może być wykryta daną metodą.

Ze względu na różnorodność metod badawczych, jakie mogą być stosowane do wykrywania nieszczelności, zostały one podzielone na trzy główne kategorie (rysunek 1) [16, 17].

Pierwsza z kategorii to metody nietechniczne, w tym biologiczne. Metody należące do tej grupy charakteryzują się niewielkim stopniem złożoności oraz brakiem konieczności stosowania skomplikowanej aparatury pomiarowej [16, 19]. Kolejną kategorię stanowią metody techniczne, wśród których wyróżnić można zarówno metody optyczne, jak i inne metody instrumentalne [16, 19]. Ostatnią kategorię metod wykrywania nieszczelności stanowią techniki obliczeniowe, które do wykrycia nieszczelności wykorzystują dane wejściowe takie jak przepływ, ciśnienie i temperatura gazu oraz odpowiednie algorytmy obliczeniowe [16, 19]. 


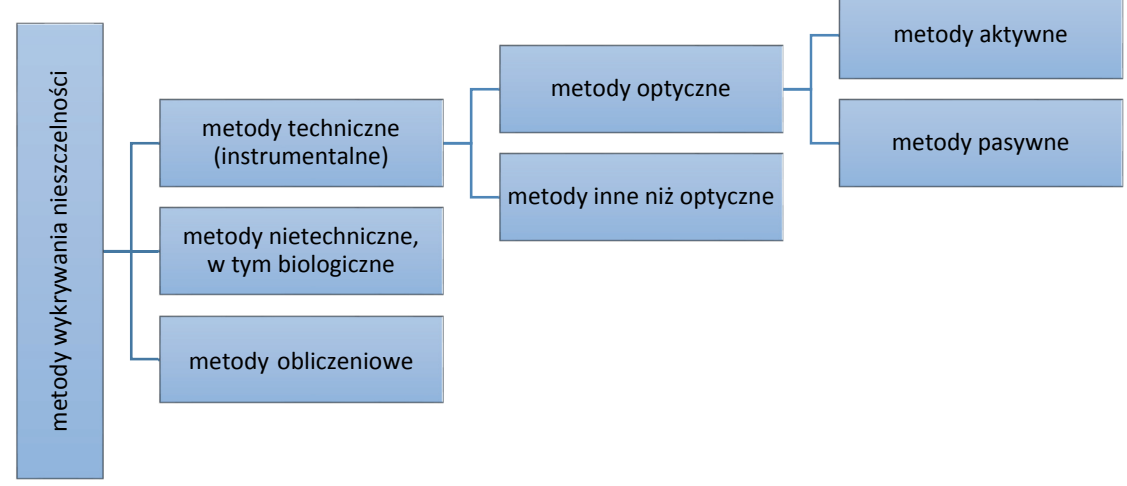

Rys. 1. Klasyfikacja metod wykrywania nieszczelności

\section{Metody nietechniczne}

Do wykrywania nieszczelności stosowane są między innymi metody nietechniczne, wśród których istotną grupę stanowią metody biologiczne. Metody biologiczne polegają na pracy specjalnie przeszkolonego personelu, który poruszając się wzdłuż gazociągu, poszukuje anomalii związanych z wyciekami gazu. Anomaliami tymi mogą być efekty wizualne, zapachowe lub dźwiękowe związane z występującą nieszczelnością $[19,28]$. Najczęściej podczas oceny szczelności gazociągów metodami biologicznymi wykorzystuje się wizualną ocenę szaty roślinnej nad gazociągiem. Metoda ta jest jednak mało selektywna, gdyż wpływ na wygląd szaty roślinnej mogą mieć również inne czynniki. Dodatkowo nie może być ona stosowana w przypadku inspekcji gazociągów zlokalizowanych na terenach wysoko zurbanizowanych. Podczas kontroli szczelności gazociągów metodami biologicznymi oprócz oceny szaty roślinnej wykorzystać można również zwierzęta, głównie specjalnie szkolone psy. W warunkach laboratoryjnych stwierdzono, że psi węch ma możliwość wykrycia metanu w powietrzu już na poziomie 500 ppt do $10 \mathrm{ppb}[16,19]$.

Popularną metodą nietechniczną (niezaliczaną do metod biologicznych) jest sposób wykrywania nieszczelności z za- stosowaniem roztworu środka spieniającego [16, 19]. Jest to bez wątpienia jedna z najprostszych, najmniej kosztownych i najbardziej dostępnych metod kontroli szczelności. Dzięki temu może ona służyć do kontroli szczelności zaworów i połączeń rozłącznych (np. kołnierze, gwinty, dławiki). Jej istotnym ograniczeniem jest jednak to, że nie może być stosowana do kontroli szczelności elementów sieci gazowych zlokalizowanych pod ziemią oraz elementów sieci wysokiego ciśnienia.

Metody nietechniczne, mimo iż są stosunkowo proste oraz nie wymagają zastosowania kosztownej aparatury pomiarowej, nie stanowią dobrego narzędzia do wytypowania miejsc prowadzenia pomiarów wielkości emisji metanu, gdyż są subiektywne i nie pozwalają na jednoznaczną identyfikację miejsca uchodzenia gazu. Wyjątek stanowi metoda z zastosowaniem roztworu środka spieniającego, jednak jej wykorzystanie podczas prowadzenia pomiarów wielkości emisji metanu na potrzeby wyznaczania współczynników emisji jest ograniczone wyłącznie do elementów nadziemnych i wymaga bardzo dużej skrupulatności oraz nakładu czasu.

\section{Metody techniczne}

Wśród metod technicznych wykrywania nieszczelności drugą grupę stanowią metody optyczne. Można je podzielić na pasywne oraz aktywne. Metody aktywne wymagają zastosowania źródła promieniowania elektromagnetycznego do przeprowadzenia monitoringu badanego obszaru, natomiast sposoby pasywne wykorzystują wyłącznie promieniowanie tła lub promieniowanie emitowane przez gaz [19].

Podstawowym zjawiskiem fizycznym wykorzystywanym do wykrywania nieszczelności gazociągów aktywną metodą optyczną jest absorpcja oraz rozpraszanie promieniowania spowodowane obecnością metanu w powietrzu. W tym celu do detekcji nieszczelności stosowane są najczęściej dwa rodzaje laserów: impulsowe lub diodowe $[2,4,16,19]$, a także milimetrowe fale radiowe $[16,19,22]$. Lasery impulsowe wykorzystywane są w systemach typu LIDAR (Light Detection and Ranging), jednak stosowanie lasera impulsowego do wykrywania nieszczelności sieci gazowych jest stosunkowo kosztownym rozwiązaniem [2]. Zdecydowanie tańsze jest zastosowanie urządzenia opartego na laserze diodowym, który generuje promieniowanie elektromagnetyczne o regulowanej długości fali [4]. Detektory tego typu charakteryzują się odpowiednio niską granicą wykrywalności, wynoszącą 5 ppm. 
Dodatkowo ich zaletą jest to, że mogą być wykorzystywane jako urządzenia ręczne oraz jako urządzenia służące do monitorowania gazociągów z samochodów lub z powietrza [7].

W aktywnych metodach optycznych do detekcji nieszczelności stosowane mogą być również milimetrowe fale radiowe $[16,19,22]$. Systemy tego typu wykorzystują fakt, że metan - jako gaz lżejszy od powietrza - migruje nad powierzchnię gruntu. W tej metodzie do detekcji nieszczelności wykorzystywana jest zarówno zmiana gęstości powietrza spowodowana obecnością metanu, jak i zjawisko rozproszenia fali przez cząstki metanu $[16,19,22]$. Dużą zaletą tego typu czujników jest fakt, że mogą pracować w każdych warunkach pogodowych oraz w różnych warunkach środowiskowych, w tym w obszarze zadymionym [7, 8].

Zaletami wszystkich aktywnych metod optycznych detekcji nieszczelności jest możliwość zamontowania odpowiednich systemów detekcji na pojazdach lub w samolotach, co znacznie usprawnia prowadzenie kontroli długich odcinków gazociagów. Drugą istotną zaletą jest ich wysoka czułość. Metody te nie są jednak pozbawione wad, do których można zaliczyć wysokie koszty zakupu i eksploatacji urządzeń oraz konieczność realizacji pomiarów przez wykwalifikowaną obsługę, a także możliwość generowania fałszywych alarmów [22].

Drugą grupę metod optycznych stanowią metody pasywne, które nie wymagają zastosowania zewnętrznego źródła promieniowania. Dzieje się tak dlatego, że w metodach pasywnych wykorzystywane jest albo promieniowanie emitowane przez gaz ziemny, albo promieniowanie tła. Istnieje kilka typów systemów detekcji pasywnej, tj.: termowizja, obrazowanie wielowidmowe lub hiperspektralne oraz filtry gazu z korelacją radiometryczną [16, 19].

Najbardziej popularnymi urządzeniami do wykrywania wycieków gazu, wykorzysującymi pasywne metody optyczne, są kamery termowizyjne. Metody termowizyjne, wykorzystując do pomiarów promieniowanie podczerwone (IR), są metodami bezkontaktowymi, a ich precyzja w dużej mierze zależy od rozdzielczości zastosowanej kamery [11]. Metody termowizyjne w wersji uproszczonej korzystają z różnicy temperatur pomiędzy ulatniającym się gazem a otoczeniem [11], natomiast w bardziej zaawansowanych wersjach wykorzystują absorpcję promieniowania podczerwonego przez cząsteczki metanu [1]. Kamery termowizyjne wykorzystujące absorpcję promieniowania podczerwonego mogą być z powodzeniem stosowane do wykrywania nieszczelności zlokalizowanych zarówno w infrastrukturze nadziemnej, jak i podziemnej [20]. Zaletami metody termowizyjnej są duża szybkość i precyzja w wykrywaniu miejsc wycieku gazu oraz możliwość realizowania pomiarów w trakcie typowej pracy instalacji.
Bardziej zaawansowanymi metodami pasywnymi niż termowizyjne są techniki oparte na obrazowaniu wielowidmowym lub hiperspektralnym [16, 19, 22]. Metody te moga wykorzystywać zarówno zjawisko absorpcji, jak i emisji. W przypadku technik emisyjnych podczas detekcji gazów ich temperatura powinna być znacznie wyższa od temperatury otoczenia. Obrazowanie absorpcyjne wykorzystuje absorpcję promieniowania tła dla różnych długości fali i może być stosowane nawet przy braku różnic temperatury pomiędzy wykrywanym gazem a otoczeniem. Istotną zaletą tych metod jest duża odporność na generowanie fałszywych alarmów, dzięki temu mogą być one z powodzeniem stosowane do wykrywania wycieków gazu ziemnego w warunkach przemysłowych, bez stałego nadzoru, jednak rozwiązania tego typu rzadko stosuje się do kontroli szczelności gazociągów $[3,19,22]$.

Ostatnią grupę pasywnych metod optycznych stanowią metody z wykorzystaniem filtrów gazu z korelacją radiometryczną (GFCR) [16, 19, 27]. Metoda GFCR pierwotnie wykorzystywana była w pomiarach teledetekcyjnych wykonywanych za pośrednictwem satelitów. W przypadku metody GFCR promieniowanie najpierw przechodzi przez wąski filtr pasmowy, następnie wiązka promieniowania jest dzielona i przechodzi wzdłuż dwóch ścieżek. Pierwsza z nich nie zawiera komórki korelacyjnej, natomiast druga posiada komórkę korelacyjną wypełnioną szukanym gazem, która działa jak filtr widmowy [27]. Badania prowadzone nad metodą GFCR pozwalają stwierdzić, że minimalny wyciek gazu możliwy do wykrycia przy jej zastosowaniu wynosi około $236 \div 3301 / \min [27]$.

Zaletami zarówno pasywnych, jak i aktywnych metod optycznych jest możliwość prowadzenia pomiarów z różnego typu pojazdów, co znacznie ułatwia kontrolę długich odcinków gazociągów.

Metody techniczne są najbardziej zróżnicowaną grupą metod służących do wykrywania nieszczelności sieci gazowych. Są one oparte na różnych podstawach fizykochemicznych, natomiast ich cechą wspólną jest to, że do przeprowadzenia kontroli szczelności z ich użyciem niezbędne jest wykorzystanie specjalistycznego sprzętu.

Podstawowymi metodami technicznymi (instrumentalnymi) stosowanymi do wykrywania nieszczelności są natomiast metody oparte na analizie składu próbki gazu. Wykorzystywane są w nich urządzenia, które wykrywają obecność węglowodorów (metanu) w powietrzu w stężeniach nieprzekraczających kilku ppm [16, 19] lub urządzenia, które mogą dodatkowo dokonywać pomiaru wielkości emisji metanu, np. Hi Flow Sampler [5]. Jednak w przypadku zastosowania urządzeń służących typowo do pomiaru stężenia metanu, przy ich użyciu do wykrywania nieszczelności należy mieć na uwadze, że rozwiązanie tego typu 
będzie czaso- i kosztochłonne. W zależności od zastosowanego rozwiązania wykorzystywane są albo urządzenia stacjonarne rozmieszczone na sieci, albo urządzenia mobilne. Metody te mogą być stosowane nawet w przypadku gazociągów podmorskich; przy tego typu gazociągach do prowadzenia ich inspekcji wykorzystywane są ROV'y (Remotely Operated Vehicle). Zaletami metod należących do tej grupy są duża czułość i selektywność, które pozwalają na wykrycie nawet niewielkich nieszczelności oraz powodują, że metody te dają stosunkowo niewielką ilość fałszywych sygnałów [16, 19]. Kolejną zaletą metod opartych na analizie składu gazu jest to, że mogą one być stosowane zarówno do kontroli szczelności infrastruktury gazowej podziemnej, jak i nadziemnej.

Wśród innych technik wykrywających nieszczelności wyróżnić można także metody akustyczne. Wykrywanie nieszczelności za pomocą sygnałów akustycznych jest możliwe, ponieważ gaz wypływający przez szczelinę lub otwór w rurociągu generuje sygnał akustyczny w zakresie odpowiadającym ultradźwiękom powyżej $20 \mathrm{kHz}[6,18]$. Informacje uzyskane dzięki odpowiednim czujnikom akustycznym są wykorzystywane do utworzenia profilu hałasu w gazociągu. Odchylenia od otrzymanego w ten sposób profilu stanowią sygnał informujący o wycieku gazu. Wadą tej metody jest konieczność montowania wielu czujników akustycznych, aby móc w sposób zdalny monitorować dłuższe odcinki gazociągów [12]. Dzieje się tak ze względu na to, że jeśli pomiędzy parą czujników akustycznych wystąpi więcej niż jedna nieszczelność, to ich prawidłowe zlokalizowanie nie będzie możliwe. Dodatkowo metoda ta nie pozwala na wykrycie niedużych nieszczelności, których sygnał akustyczny nieznacznie różni się od szumów. Można wprawdzie zwiększyć czułość metody poprzez dobór odpowiednich progów detekcji, doprowadzi to jednak prawdopodobnie do generowania dużej ilości fałszywych alarmów [6].

Do metod technicznych należą również metody z zastosowaniem substancji znacznikowej. Jako substancje znacznikowe wykorzystywane mogą być zarówno znaczniki elektroujemne (heksafluorek siarki czy perfluorowęglowodory), jak i węglowodory nienasycone (np. eten), a także znaczniki radioaktywne (głównie bromek metylu znakowany bromem ${ }^{82} \mathrm{Br}$ ) [9, 13-15, 26, 29]. Kontrola szczelności gazociągów metodą znacznikową polega na wstrzyknięciu do gazociągu małej ilości znacznika. Znacznik wraz z gazem ziem- nym będzie przenikać $\mathrm{z}$ gazociągu do gleby w miejscu występowania nieszczelności $[16,19]$, gdzie następuje pomiar zawartości substancji znacznikowej w powietrzu lub w przypadku znaczników radioaktywnych pomiar radiometryczny promieniowania gamma. Niezależnie od tego, jaki typ znacznika zostanie wykorzystany, istotną przeszkodą w prowadzeniu kontroli szczelności gazociągów metodami znacznikowymi może być brak odpowiedniej infrastruktury umożliwiającej wprowadzenie znacznika do gazociągu.

Do wykrywania nieszczelności gazociągów wykorzystać można również czujniki w postaci odpowiednich przewodów elektrycznych $[16,19]$. W przypadku tego typu metod można spotkać dwa rozwiązania. W pierwszym z nich przewód elektryczny jest wykonany z materiału, który reaguje w kontakcie z węglowodorami. W wyniku zachodzących reakcji zmianie ulegają niektóre właściwości przewodów elektrycznych (np. pojemność czy impedancja), które są monitorowane w celu wykrycia nieszczelności [16, 19, 23]. Podczas konstruowania układów detekcji nieszczelności gazociągów z użyciem przewodów elektrycznych wykorzystywane może być również drugie rozwiązanie, w którym węglowodory oddziałują na powłokę izolacyjną przewodu. W wyniku tego oddziaływania następować może pęcznienie lub degradacja powłoki izolacyjnej. W takim przypadku przy odpowiednim ułożeniu przewodów elektrycznych dochodzić będzie do zwarcia w miejscu wystąpienia wycieku, które generuje sygnał alarmowy [16, 19, 23].

Podobną do opisanej powyżej metody jest technika wykorzystująca czujniki światłowodowe do wykrywania nieszczelności na gazociągach. Zastosowanie światłowodów do ciągłego monitorowania wycieków gazu opiera się na zjawiskach fizycznych, które występują w miejscu wycieku. Jednym $\mathrm{z}$ nich jest zmiana temperatury powstająca w momencie adiabatycznego rozprężania gazu. Miejscowy spadek temperatury, który występuje w miejscu wycieku, powoduje zmiany w profilu temperatury $[6,23]$. W celu wykrycia takich zmian światłowód umieszcza się wzdłuż gazociągu, a następnie przy użyciu impulsów laserowych badany jest profil temperaturowy [25]. Zaletą tej metody jest duża dokładność w lokalizowaniu miejsca wystąpienia nieszczelności. Znajduje ona zastosowanie przede wszystkim w instalacjach technologicznych, a w mniejszym stopniu wykorzystywana jest przy gazociągach dalekosiężnych [23].

\section{Metody obliczeniowe}

Ostatnią grupę metod służących do wykrywania nieszczelności zlokalizowanych na gazociągach stanowią metody, które wykorzystują dane wejściowe (uzyskiwane np. dzięki systemowi SCADA), takie jak przepływ, ciśnienie i temperatura gazu, oraz odpowiednie algorytmy obliczeniowe $[16,19]$. Najbardziej podstawowymi metodami należącymi do tej grupy są techniki oparte na bilansie strumienia masy lub objętości na wejściu i wyjściu z badanego odcinka 
gazociągu [6, 16, 19, 21, 23, 28]. Rozbieżność pomiędzy ilością gazu wprowadzoną do systemu a ilością zmierzoną na wyjściu może wskazywać na występowanie nieszczelności gazociągu. Dokładność tej metody zależy od dokładności przyrządów pomiarowych. Dodatkowo technika ta daje dużo lepsze wyniki w przypadku ustalonych w czasie przepływów gazu. Zmienny w czasie odbiór gazu w punktach wyjścia może prowadzić do powstawania fałszywych alarmów lub wydłużać czas wykrycia nieszczelności $[16,19]$. Prawidłowe funkcjonowanie tej metody i właściwa interpretacja wyników opiera się w głównej mierze na zastosowaniu odpowiednich wartości progowych świadczących o występowaniu nieszczelności, które uwzględniają m.in. zmiany temperatury gazu, kradzieże gazu oraz błędy układów pomiarowych. Istotną wadą tej metody jest to, że nie pozwala ona na bezpośrednie zlokalizowanie miejsca występowania nieszczelności, a jedynie na wskazanie odcinka gazociągu, na którym ta nieszczelności wystąpiła [23].

Metodami bilansowymi, które mogą być realizowane na wybranym odcinku gazociągu, a jednocześnie nie wymagają ingerencji w gazociąg, są metody z wykorzystaniem gazomierzy ultradźwiękowych. W przypadku tych metod do wykrycia nieszczelności konieczny jest podział badanego odcinka gazociągu na segmenty, z których każdy jest ograniczony na końcach przez podstawowe stacje pomiarowe, gdzie mierzone lub obliczane są takie parametry jak: strumień objętościowy gazu, temperatura gazu i otoczenia oraz prędkości dźwięku w danym medium. Wszystkie dane uzyskane na stacjach podstawowych są zbierane przez stację główną, która bilansuje objętość gazu, porównując różnice w objętości gazu wchodzącego i wychodzącego z każdego segmentu rurociągu. W zależności od czasu trwania okresów bilansowania metoda ta pozwala na wykrywanie dużych nieszczelności w bardzo krótkim czasie lub drobnych nieszczelności przy wydłużonych okresach bilansowania. Dużą zaletą tych metod jest to, że pozwalają one zlokalizować wyciek z dokładnością nawet do 150 metrów [16, 19]. Dodatkowo zastosowanie gazomierzy typu clamp-on umożliwia bezinwazyjne zainstalowanie na gazociągu podstawowych stacji pomiarowych. Z drugiej strony konieczność odkopania gazociągu i wyposażenia go w gazomierze ultradźwiękowe znacząco podnosi koszty prowadzenia kontroli jego szczelności z użyciem tej metody.

Udoskonaleniem metody opartej na bilansie strumienia masy lub objętości są techniki określane jako RTTM, czyli metody modeli przejściowych w czasie rzeczywistym $[6,16,19]$. W przeciwieństwie do metod opartych na bilansie strumienia masy lub objętości pozwalają one na kompensację dynamicznych zmian zachodzących $\mathrm{w}$ gazociągu. W tym celu do wykrywania nieszczelności wykorzystywane są zasady zachowania masy, pędu i energii [6]. Na podstawie danych wejściowych, czyli wyników pomiaru ciśnienia i temperatury na wejściu i wyjściu z gazociągu, przy użyciu odpowiednich równań można obliczyć oczekiwane natężenia przepływu gazu na wlocie i wylocie gazociągu. Różnice w wyliczonych wartościach w porównaniu $\mathrm{z}$ wartościami zmierzonymi pozwalają na określenie, czy na danym odcinku gazociągu występuje nieszczelność. W przypadku metod RTTM różnice te są znacznie łatwiejsze do zidentyfikowania niż w metodzie opartej na bilansie strumienia masy lub objętości. Stąd też RTTM pozwala na wykrycie mniejszych nieszczelności oraz generuje mniejszą liczbę fałszywych alarmów $[6,25]$.

Kolejną metodą obliczeniową jest technika oparta na analizie ciśnień punktowych, która bazuje na założeniu, że jeśli na gazociągu występuje nieszczelność, to ciśnienie gazu spada $[19,24,28]$. Metoda ta wymaga prowadzenia ciągłego pomiaru ciśnienia w różnych punktach wzdłuż gazociągu. Rozmieszczenie czujników ciśnienia zależy głównie od przebiegu gazociągu; strome wzniesienia wymuszają zagęszczenie rozmieszczenia czujników ciśnienia [16, 19]. Wykrycie nieszczelności następuje poprzez porównanie otrzymanych wyników pomiaru ciśnienia gazu w gazociągu z wartością średnią. Jeśli wynik pomiaru jest niższy od wartości średniej o założoną wartość progową, wtedy uznaje się, że badany odcinek gazociągu jest nieszczelny $[16,19]$. Istotną wadą metody polegającej na ciągłym pomiarze ciśnienia jest to, że nie daje ona wiarygodnych wyników dla nieustalonych w czasie przepływów gazu. Dodatkowo wielkość wycieku, jaki może być wykryty przy użyciu tej metody, w dużej mierze zależy od objętości gazociągu; im większa objętość gazociągu, tym większe wycieki mogą być wykrywane daną metodą $[16,19]$.

Ostatnią grupę metod obliczeniowych stanowią metody statystyczne $[6,16,19]$. Analiza statystyczna jest najprostszym sposobem wykrywania nieszczelności gazociągów bez konieczności stosowania modelu matematycznego. W metodzie tej prowadzona jest analiza parametrów takich jak ciśnienie i przepływ gazu, mierzonych w wielu miejscach wzdłuż gazociągu. Alarm sugerujący występowanie nieszczelności jest generowany tylko wtedy, gdy zmierzone wartości odbiegają w sposób statystycznie istotny od założonych. Dlatego przy wprowadzaniu metody statystycznej do wykrywania nieszczelności gazociągów ważne jest strojenie systemu, które polega na analizie zmienności parametrów systemu w różnych stanach pracy gazociągu. Strojenie systemu odbywa się przy braku występowania w układzie nieszczelności. Jeśli na etapie strojenia w układzie występuje nieszczelność, zostanie ona potraktowana jako prawidłowa praca systemu, a co za tym idzie wycieki tej wielkości nie będą wykrywane 
przy użyciu zestrojonej w ten sposób metody. W trakcie etapu strojenia ustala się również progi, po przekroczeniu których generowane są alarmy wskazujące na występowanie nieszczelności. Analizowana jest także zmienność parametrów w różnych stanach pracy gazociągu przy braku występowania nieszczelności. Odpowiednie przeprowadzenie procesu strojenia wpływa na dokładność metody i pozwala na skuteczną eliminację fałszywych alarmów.

Dużą zaletą wszystkich metod obliczeniowych jest to, że do wykrywania nieszczelności gazociągów wykorzystuje się dane o systemie, które i tak w większości są gromadzone ze względów technologicznych. Jednak ich skuteczność w dużej mierze zależy od zastosowanych algorytmów obliczeniowych, aparatury pomiarowej oraz przyjętych progów detekcji nieszczelności. W związku z tym trudno jednoznacznie określić, jakiej wielkości wycieki mogą być wykrywane daną metodą. Istotną wadą metod obliczeniowych jest jednak fakt, że pozwalają one jedynie na przybliżoną lokalizację miejsca występowania wycieku, w wielu miejscach ograniczoną wyłącznie do wskazania nieszczelnego odcinka gazociągu.

\section{Podsumowanie i wnioski}

Przeprowadzony przegląd pokazał, że istnieje wiele metod wykrywania nieszczelności w obrębie sieci gazowych. Jednak niektóre z nich mogą nie mieć zastosowania w przypadku infrastruktury podziemnej (np. metoda z użyciem roztworu środka spieniającego) lub ich wykorzystanie przy gazociągach jest ograniczone z przyczyn technicznych (metody znacznikowe). Kontrola szczelności gazociągu na potrzeby prowadzenia pomiarów wielkości emisji metanu w głównej mierze powinna koncentrować się na jak najdokładniejszym wskazaniu miejsca występowania nieszczelności, które będzie jednocześnie punktem pro- wadzenia pomiarów wielkości emisji metanu. Metodami dobrze nadającymi się do wykrywania nieszczelności są metody techniczne (instrumentalne), zarówno te optyczne, jak i nieoptyczne. Dobór odpowiednich metod wykrywania nieszczelności, należących do grupy metod instrumentalnych, pozwala na wskazanie miejsca występowania nieszczelności z odpowiednią dokładnością, niezbędną do przeprowadzenia pomiarów wielkości emisji metanu. Niestety metody należące do tej grupy charakteryzują się wysokimi kosztami zakupu i eksploatacji sprzętu niezbędnego do prowadzenia badań.

Prosimy cytować jako: Nafta-Gaz 2017, nr 11, s. 871-877, DOI: 10.18668/NG.2017.11.07

Artykuł nadesłano do Redakcji 24.05.2017 r. Zatwierdzono do druku 6.07.2017 r.

Artykuł powstał na podstawie pracy statutowej pt.: Analiza możliwości oceny wielkości emisji metanu z sieci gazu ziemnego - praca INiG - PIB na zlecenie MNiSW; nr zlecenia: 0062/GE/16, nr archiwalny: DK-4100-62/16.

\section{Literatura}

[1] Basiura M., Rataj M.: Wykrywanie nieszczelności w instalacjach i urzadzeniach gazowych za pomoca metody obserwacji w paśmie podczerwieni. Gaz, Woda i Technika Sanitarna 2013, nr 11, s. $426-429$

[2] Bobrovnikov S.M., Serikov I.B., Arshinov Y.F., Sakovich G., Vorozhtsov A., Eisenreich N.: Remote Detection of Leaks in Gas Pipelines with an Airborne Raman Lidar. Strategic Insights 2008, vol. VII, nr 1.

[3] Cosofret B.R., Marinelli W.J., Ustun T., Gittins C.M., Boies M.T., Hinds M.F., Rossi D.C., Coxe R., Chang S.: Passive infrared imaging sensor for standoff detection of methane leaks. SPIE Optics East Chemical and Biological Standoff, Filadelfia 2004.

[4] Demusiak G.: Nowe metody kontroli szczelności sieci i instalacji gazu ziemnego, z wykorzystaniem ręcznych detektorów laserowych do zdalnego wykrywania wycieków metanu. Nafta-Gaz 2010, nr 4, s. 287-296.

[5] Demusiak G.: Wybrane metody pomiaru $i$ zastosowania metod obliczeniowych do wyznaczania wielkości emisji metanu na ttoczniach gazu. Gaz, Woda i Technika Sanitarna 2014, nr 12, s. 454-459.

[6] Fiedler J.: An overview of pipeline leak detection technologies. Krohne Inc.; http://asgmt.com/wp-content/uploads/2016/02/004 pdf (dostęp: 23.06.2013).

[7] Frish M.B., Wainner R.T., Green B.D., Laderer M.C., Allen M.G.:
Standoff gas leak detectors based on tunable diode laser absorption spectroscopy. Spie Optics East 2005.

[8] Gopalsami N.: Millimeter-wave radar sensing of airborne chemicals. IEEE Transactions on Microwave Theory and Techniques 2001, vol. 49, s. 646-653.

[9] Holewa J., Rachwalski J.: Kontrola szczelności podziemnych struktur przeznaczonych do magazynowania paliw gazowych, metoda znacznikowa i powierzchniowego monitoringu gazu glebowego. Nafta-Gaz 2009, nr 5, s. 410-414.

[10] Holewa-Rataj J., Kukulska-Zając E.: Przegląd współczynników emisji metanu dla gazociagów. Gaz, Woda i Technika Sanitarna 2017, nr 7, s. 282-288.

[11] Jadin M.S., Ghazali K.H.: Gas Leakage Detection Using Thermal Imaging Technique. $16^{\text {th }}$ International Conference on Computer Modeling and Simulation 2004, s. 301-305.

[12] Jin H., Zhang L., Liang W., Ding Q.: Integrated leakage detection and localization for gas pipelines based on the acoustic wave method. Journal of Loss Prevention in the Process Industry 2014, vol. 27, s. 74-88.

[13] Kraś J., Nobis C., Myczkowski S.: Leakage control methods for metal underground tanks and tanks placed on hardened soil with the use of radioactive tracers. Nukleonika 2008, vol. 53, s. 137-140.

[14] Kraś J., Waliś L., Myczkowski S.: Zastosowanie metody znacz- 
ników promieniotwórczych do kontroli szczelności i lokalizacji nieszczelności w rurociagach podziemnych. Postęp Techniki Jądrowej 1999, vol. 42, z. 4, s. 22-26.

[15] Kung J.K.: Use of Sulfur hexafluoride and Perfluorocarbon Tracers in Plutonium Storage Containers for Leak Detection. Amarillo National Resource Center for Plutonium 1998, Report ANRCP-1998-4, s. 28-31.

[16] Mandal P.C.: Gas Leak Detection in Pipelines \& Repairing System of Titas Gas. Journal of Applied Engineering (JOAE) 2014, vol. 2, nr 2, s. 23-34.

[17] Mandal P.C., Chowdhury S., Morshed S.M.: Fugitive methane emissions from the natural gas distribution network of Titas Gas and the environmental risks. WIT Transactions on Ecology and The Environment 2015, vol. 206, s. 137-148.

[18] McAllister E.W.: Pipelines rules of thumb handbook. Fifth edition 2002, s. 522-531.

[19] Murvaya P.S., Sileaa I.: A survey on gas leak detection and localization techniques. Journal of Loss Prevention in the Process Industries 2012, vol. 25, s. 966-973.

[20] Rataj M., Basiura M.: Wykrywanie emisji gazów węglowodorowych przy wykorzystaniu kamery termowizyjnej FLIR GF320. Gaz, Woda i Technika Sanitarna 2012, nr 9, s. 366-369.

[21] Rougier J.: Probabilistic leak detection in pipelines using the mass imbalance approach. Journal of Hydraulic Research 2005, vol. 43, nr 5, s. 556-566.

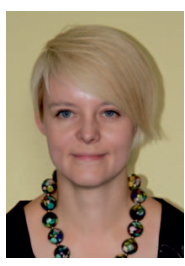

Mgr Jadwiga HOLEWA-RATAJ

Starszy specjalista badawczo-techniczny w Zakładzie Ochrony Środowiska.

Instytut Nafty i Gazu - Państwowy Instytut Badawczy ul. Lubicz $25 \mathrm{~A}$

31-503 Kraków

E-mail: jadwiga.holewa@inig.pl
[22] Sivathanu Y.: Technology Status Report on Natural Gas Leak Detection in Pipelines. U.S. Department of Energy, National Energy Technology Laboratory, Contract Number: DE-FC26-03NT41857.

[23] Sobczak R., Turkowski M., Bratek A., Słowikowski M., Bogucki A.: Metody i systemy detekcji nieszczelności rurociagów dalekosięznych. Pomiary Automatyka Robotyka 2007, nr 4, s. 15-19.

[24] Steczko K., Rachwalski J.: Emisja metanu z sieci rozdzielczej gazu ziemnego. Nafta-Gaz 2007, nr 6, s. 412-423.

[25] Strona internetowa: http://krohne.com/fileadmin/content/media-lounge/PDF-Download/Oil_and_Gas/PR_PipePatrol_OilReview_Africa_LoRes.pdf (dostęp: 16.08.2016).

[26] Strona internetowa: http://www.barc.gov.in/rcaindia/rca indian_expertise_industry_1.html\#Tracers (dostęp: 28.06.2016).

[27] Tolton B., Banica A., Miller D.: Results of field trials of realsens, an airborne natural gas leak detection technology. International Gas Union Research Conference, Paris 2008.

[28] Zhang J.: Designing a Cost Effective and Reliable Pipeline Leak Detection System. Pipeline Reliability Conference, Houston, USA, 19-22.11.1996, s. 1-11.

\section{Patent}

[29] United States Patent 20040072355 Continuous tracer generation method.

\section{OFERTA}

\section{ZAKŁAD GEOFIZYKI WIERTNICZEJ}

Zakres działania:

- badania tomograficzne skał:

" trójwymiarowa wizualizacja i analiza wewnętrznej struktury przestrzeni porowej skał metodą mikrotomografii rentgenowskiej (micro-CT)

" tomografia metrowych odcinków skał, profilowanie zmian parametrów petrofizycznych rdzenia (porowatośc, gęstość objętościowa);

- badania metodą jądrowego rezonansu magnetycznego:

" określanie rozkładu nasycenia wodą przestrzeni porowej próbek,

generacja map T1-T2, szacowanie nasycenia woda/węglowodorami, identyfikacja obecności substancji organicznej TOC;

- $\quad$ oznaczanie jakościowego i ilościowego składu mineralnego skał oraz wydzielonej frakcji ilastej na podstawie analizy rentgenowskiej;

- $\quad$ wyznaczanie zawartości naturalnych pierwiastków promieniotwórczych: uranu, toru i potasu w skałach, płuczkach wiertniczych i materiałach budowlanych;

- $\quad$ ocena elektrycznych parametrów skał (wskaźnika struktury porowej i zwilżalności);

- określanie zależności elektrycznej oporności właściwej płuczek wiertniczych od temperatury;

- $\quad$ ocena prędkości propagacji fal ultradźwiękowych w skałach, kamieniach cementowych i płuczkach wiertniczych;

- $\quad$ badanie przewodności cieplnej skał;

- $\quad$ wyznaczane wspó́czynnika przepuszczalności

- badanie gęstości, gęstości właściwej i porowatości

- interpretacja profilowań geofizycznych w zakresie oceny stanu zacementowania rur okładzinowych w otworach;

- badania serwisowe:

» analiza chemiczna skał metodą fluorescencji rentgenowskiej

" spektrometryczne pomiary gamma na rdzeniu wiertniczym: ${ }^{40} \mathrm{~K},{ }^{238} \mathrm{U},{ }^{232} \mathrm{Th}$, total gamma przy wykorzystaniu mobilnego urządzenia "Gamma Logger".

Kierownik: dr inż. Marek Dohnalik

Adres: ul. Bagrowa 1, 30-733 Kraków

Telefon: 126506770

Faks: 126177470,126531665

E-mail: marek.dohnalik@inig.pl

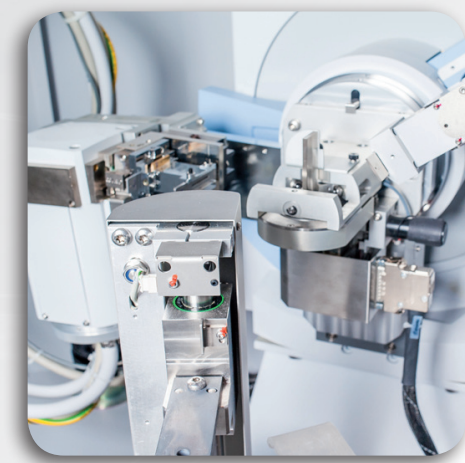

EWa KUKUISKA-ZAJAC

ul. Lubicz 25 A

31-503 Kraków

E-mail: kukulska@inig.pl 